\section{Social Work} \& Education

๑ SW\&E, 2019

UDC 378.6

DOI: $10.25128 / 2520-6230.19 .2 .10$

\section{Maria Karantoni,}

$\mathrm{PhD}$ student, Greece.

e-mail: mkarantoni83@gmail.com
Karantoni, M. (2019). Access to higher education and social inequalities: social characteristics of the students of the school of educational sciences, Social Work and Education, Vol. 6, No. 2., pp. 213-219. DOI: 10.25128/2520-6230.19.2.10

\section{ACCESS TO HIGHER EDUCATION AND SOCIAL INEQUALITIES: SOCIAL CHARACTERISTICS OF THE STUDENTS OF THE SCHOOL OF EDUCATIONAL SCIENCES}

\begin{abstract}
The article investigates social inequalities in access to higher education. This issue became of particular concern both in Greece and at the international level.
\end{abstract}

The aim of this study was to investigate the sociodemographic characteristics of students of the School of Educational Sciences and their changes during 20012009 on such criteria as: a) the father's profession; b) the mother's profession; c) the level of education of the mother and d) the gender of students. Students of Schools of Educational Sciences constituted the reference population of this research.

It was established that students of Schools of Educational Sciences came from a social environment with low economic, educational and social capital. The representation of female students in that type of institution was five times higher than that of male students, reflecting societal stereotypes of children's education as a female profession. In the last years of the period under the review these peculiarities of the students' contingent have become less pronounced due to the increase in the number of students from families with high educational level of parents and an increase in male students. However, Schools of Educational Sciences still remain one of the "social elevators" for people from the lower social classes of society.

Key words: higher education; social inequality; access to higher education; student; gender differences; educational sciences.
Article history:

Received: January 21, 2019

1st Revision: May 20, 2019

Accepted: June 30, 2019 


\section{Introduction}

This article examines social inequalities in access to higher education. In particular, it focuses on the social characteristics of students in the School of Educational Sciences, during the period 2001-2009. This is a matter of interest because during the last years of the period under review, the bases for admission to the Schools of Educational Sciences and in particular to the Pedagogical Departments of Primary Education showed a significant increase. This raises the question whether this evolution of the bases has affected the social characteristics of the students. Another reason is that social inequalities in access to higher education are the subject of many theoretical and empirical studies both in Greece and internationally.

\section{Literature review}

Survey data show that the education system reproduces social inequalities with remarkable stability. However, the way of reproduction of social inequalities in recent years has been transformed as higher education had to respond to the pressures of enlargement and democratization and, on the other hand, to maintain its reproductive role (Panagiotopoulos \& Thanos, 2008: 6465).

As Bourdieu (2002: 200201) mentions in the study of social inequalities in education, all transformations in the education system should be taken into account, but also outside those determined by the massive increase in the student population and all changes in the outcome of morphological transformations that have occurred at all levels of the educational system that have affected the organization and functioning of the educational system.

An exemplary example is the proliferation of invisible hierarchical directions and disguised marginal and non-future branches, which contribute to the vague perception of hierarchies. While previously the education system with clear frontiers led to the internalization of the various school distinctions that clearly corresponded to "social divisions" today, with the confused and unclear classifications "favors or allows" aspirations, which are also confused and unclear. In Greece, in recent years, research into social inequalities in higher education has not focused on access to the whole as much as to higher education, and in particular to the internal hierarchy of higher education. Specifically, in higher education, which was mainly intended for people from the most socially disadvantaged categories, people of different social backgrounds come together (Panagiotopoulos \& Thanos, 2008: 63).

Thus, today, the interest of surveys on social inequalities in higher education is not limited to access to the whole of higher education as a component of its democratization, for two main reasons: (a) the higher the chances of admission to higher education are not shown by (b) "low" social strata are more likely to be imported than in other countries (Thanos, 2010 - Frangoudakis, 1985 • et al.). Higher education in Greece fulfills its reproductive role through the internal hierarchy of schools, which is in fact a social hierarchy.

The prioritization of schools on the basis of the professional and generally the social perspectives they offer corresponds to the hierarchy of the schools based on the social composition of their students. In "privileged" schools, people with parents from the "upper" social strata have the greatest chances of admission, while those with "inferior" social backgrounds have the lowest chance of admission. On the other hand, in "unprivileged" schools, people with parents from the "upper" social strata have the lowest chances of admission, while those with "inferior" social strata have the greatest chances of admission (Thanos, $2010 \& 2012$ • SianouKirgiou, 2008 - Kontogiannopoulou, 1999 • Tsoukalas, $1986 \cdot$ Frangoudakis, $1985 \cdot$ and others).

Schools of Educational Sciences based on the social composition of the students and the professional perspectives they offer are ranked in the "non-privileged" faculties. 
From earlier (Vamboukas, 1982 • Pyrgiotakis, 1992 • et al.) And recent surveys (Thanos, 2012 • Karamasini \& co, 2008, etc.) it appears that teachers and kindergarten come from the "inferior" social layers, mainly of rural areas. The social status and prestige of primary school teachers is low. According to research data, teachers often think that their profession is of low social status, even from what places them in the community.

They attribute their economic situation, the nature of the subject matter of their work (young children), the length of their studies to the past (bachelor studies) and the high percentage of women in the School of Educational Sciences as the main causes of their low social status Pyrgiotakis, 1992: 182-187 • Korosis \& Eleftherakis, 2011: 78-79).

In spite of the inclusion of the Schools of Educational Sciences in the lower positions of the social hierarchy, the introduction to these schools requires a high score. In recent years, the Pedagogical Departments of Primary Education of Schools of Educational Sciences are among the most sought after candidates in university departments because of their direct employment in public and private elementary schools (Karamasini et al., 2008: 232).

It is characteristic that the appointment of "substitute" teachers, until recently, was even with the graduation certificate. Direct employment is the most important factor in the selection of Primary Education Departments (Konstantinou \& Mihos, 2011: 70-73). Students with low social and economic capital, who could be admitted to a Polytechnic or Medical School, choose to enter Primary Education Departments due to their direct absorption into the labor market (Thanos, 2009: 22-23). In the Pedagogical Departments of Kindergartens the import base is lower, but seems to be the next choice of several candidates who fail to enter the Pedagogical Departments of Primary Education (Korosis \& Eleftherakis, 2011: 87).

At the end of the 2000s, some people with high performance in the Pan-Hellenic examinations, with whom they could be admitted to some faculty of Health Sciences or Polytechnic Schools, choose to enter the Schools of Educational Sciences. and especially the Pedagogical Departments of Primary Education (Sianou, Kyrgiou \& Tsiplakides, 2011 - Thanos, 2009). The question is to what extent has this trend changed the social characteristics of the students of the Schools of Educational Sciences? This question was the reason for carrying out the research presented below.

\section{Research results}

The aim of the present study was to investigate the social characteristics of the students of the School of Educational Sciences and their evolution during the period 20012009 on the basis of: a) the father's profession; b) the profession of mother; c) the level of education of the mother, and d) their sex. The examination of the social characteristics is carried out in all the Schools of Educational Sciences, as well as in the individual Pedagogical Departments of Primary Education (PEDD) and Kindergarten (PTN).

This study is expected to contribute to the sociology of the teacher's profession in primary education. Students of Education Schools constitute the reference population of this research. Source of statistics is the Statistics of Education issued by the Hellenic Statistical Authority (ELSTAT, former ESYE) for each academic year. Data refer to the period from the academic year 2001/02 to 2008/09.

In most studies, professional groups are classified into social classes or social categories or social strata. Classification in social strata or social classes is usually used because they are broader groupings in relation to classification in social classes (Lambiri Dimaki, 1974: 90). The ranking of professional groups and their assignment to social categories or social strata is based on the degree of their socio-economic power and their prestige. The prestige, however, is "probable", since it is judged according to the personal 
judgment of each researcher, which stems from the Greek social reality (Lambiri Dimaki, 1974: 8990, 122).

Until 1992, the professional groups / categories used by EL.STAT. include unequal professions in terms of prestige and socio-economic power. ELSTAT. when classifying the professions into groups, does not take into account some sociologically relevant criteria, such as the economic or social prestige of each occupation. This results in the difficulty of classifying professional groups into social strata or social categories. The problem of classifying the professions in groups by EL.STAT. is highlighted by the majority of researchers (Droupopoulos, 1989: 23 - Lambiri-Dimaki, 1974: 122).

The change of the way of classification of the professions by ELSTAT. in 1992, did not solve the problem, since the categorization of professions was not based on sociological criteria. For example, in the "big" professional group "Members of Parliament, senior and executive executives of the public and private sector" are included ministers, deputies, secretaries-general, mayors, mayors, etc. (ESYE, 1995: 10). In surveys of social inequalities in higher education, professional groups, also referred to as socio-occupational groups due to the social dimension of the profession, are classified into three broader categories: (a) "upper" social strata (b) "middle" social strata "Technologist" and (c) 'inferior' social classes (Specialists in agriculture, livestock farmers and forestry workers), Office workers and related professions and Employees in the provision of services and vendors in shops and open-air markets and "Fishermen", "Specialists in Crafts and Associated Technical Professions", "Operators of Fixed Industrial Installations and Assemblies", and "Unskilled Workers, Handwritten and Minor Workers" (Thanos, 2010: 262 \& 2012: 130).

\section{Discussion}

According to the French sociologist Bourdieu (1989), all the institutions of higher education are a field whose organization of the structure of the contradictions is homologous to the structure of the social space (Panagiotopoulos, 1995: 25). The main opposition that characterizes the organization of the field of higher education, as pointed out by K. Tsoukalas (1987: 132-133) and in other studies (eg Fragoudakis, 1985), refers to the "state-oriented" Non-state-oriented "higher schools.

This opposition is homologous to the social stratification in Greece of the liberal professions, in which most of the ruling class (in the narrow sense) and the small and medium-sized professions is reproduced. Graduates of "non-state-oriented" schools, mainly from the "middle" and "upper" social classes, occupy the highest social positions, even in the public sector. On the other hand, graduates of "state-oriented" schools, coming from the "lower" and "small- and medium-sized" social strata, are trying to improve (in the case of the lower and middle societal positions of the public sector) (In the case of the "small" social strata) or to maintain (in the case of "small and medium" social strata) their social position (Tsoukalas, 1986: 133 - Thanos, 2010: 447-449).

Schools of Educational Sciences belong to the "state-oriented" faculties of higher education. Graduates of these schools are employed as teachers or nurses, professions, which enjoy a low social standing, as they themselves (Pyrgiotakis, 1992: 183). The students of these schools come from social environments with low economic, social and educational capital (Karamasin \& co., 2008: 232). The largest capped chances of admission are those with parents from lower socio-occupational categories (skilled farmers, craftsmen and unskilled workers) and low educational background (primary school graduates). In terms of gender, women are almost five times more likely to be introduced than men by reproducing the social stereotypes according to which child education is a female role (Arnot, 2004 • Reay, 1998). 
Schools of Educational Sciences are characterized by the contrast between the PEDs. and PT.N. This contrast corresponds to contradictions between: (a) scientific professions and other social professional classes based on the profession of parents; (b) graduates of higher education institutions and other educational levels based on the level of education of parents; and (c) men and women with based on sex. Specifically, people with parents in the scientific professions and graduates of AEI who are gender-specific are more likely to be admitted to PITs. and lower in PT.N.

During the examined period 2001-2009, there is a tendency to reduce the differences in the reserved probability of admission to School of Educational Sciences among young people with parents from the upper and lower socio-occupational categories (graphs 13 and 14). The same trend is being discarded as regards the reserved chances of introducing among young people with parents from upper and lower educational grades.

\section{Conclusion}

In the 2000s, in Schools of Educational Sciences, most of the committed chances of insertion are those with parents from the "inferior" socio-professional classes and from the lower educational levels, ie from families with low socio-economic and educational capital. Therefore, Schools of Educational Sciences do not attract individuals with high socio-economic and educational backgrounds. This means that these schools are still an instrument of social mobility for people from the grassroots and the small and mediumsized social strata.

In the last years of the period under review (academic years 2007/8 and 2008/9), Schools of Educational Sciences seem to attract the interest of individuals with parents from the "higher" socio-professional and educational categories. This development is related to the direct absorption of graduates of the Schools of Education from the labor market and the parallel decrease of the absorption of graduates of "privileged" schools from the labor market.

Education Schools are included in the "women-dominated" higher schools as women constitute the majority of students. This is directly related to the employment of graduates in pedagogical professions, which until recently have been described as "female" occupations. Between the two Pedagogical Departments, Primary Education and Kindergarten, people do not have any differences in their social characteristics. Exceptions are those with parents in the scientific professions and graduates of HEIs and boys, which have higher reserved chances of admission to PITs than in PITs. It is evident that in recent years, especially after the economic recession and the general crisis in Greek society, the strategies of reproduction of social groups have been transformed. In particular, the large decline in public sector jobs, the main absorber of higher education graduates, has significantly influenced the reproductive strategies of Greek families. These transformations have also affected the research field of social inequalities in education, which places particular emphasis on the social inequalities of graduates in accessing the labor market.

\section{References}

Arnot, M. (2004). Sex reproduction procedures. Educational Theory and Feminist Policies (V. Deligianni Koumtzi, Prof. C. Athanasiadou \& K. Dalakouras, Met.). Athens: Metaxchio.

Vambouka, M. (1982). Incentives of the teaching profession. Heraklion: Ed.

Bourdieu, P. (1989). La Noblesse d 'État. Paris: Minuit.

Bourdieu, P., \& Passeron, J.C. (1993). Heirs. Students and Culture (N. Panagiotopoulos, N. Panagiotopoulos \& M. Vidalis, Metr.). Athens: Dolphin. 
YOU RIGHT. (1995). Statistical Classification of Occupations, STEP92. Athens: ESYE

Thanos, Th. (2009). Introduction: Methodological, theoretical and empirical issues in the study of educational inequalities in Greece. In Th. Thanos (Ed.): Educational inequalities: Methodological, theoretical and empirical issues [Proceedings of a Scientific Conference, Rethymno, 1132009]. Athens: Pattern, 19.32.

Thanos, Th. (2010). Sociology of social inequalities in education. The access of socio-occupational groups to higher education (G. Kuzelis, Preliminary). Athens: Island.

Thanos, Th. (2012). School divisions and social discrimination: The access of social groups to higher education at the beginning of the 21st century. Social Sciences (N. Panagiotopoulos, Director), 1, 2012, 125172.

Karamesin, M. \& amp; (2008). The absorption of university graduates into the labor market. Pan-Hellenic research in graduates of 19982000. Athens: Dionikos.

KontogiannopoulouPoludoridis, G. (1999). Educational policy and practice. Sociological analysis. Athens: Greek Letters.

Korosis, K., \& Eleftherakis, Th. (2011). The social factors that influence the choice of the educational profession: From the Pedagogical Academies and the Schools of Kindergarten in the Pedagogical Departments. In V. Economidis (Ed.): Teacher education and training. Theoretical and research approaches. Athens: Field, 7595.

Kyridis, A. The inequality in Greek education and access to the university (19551985). Athens: Gutenberg.

Konstantinou, X, \& Mihos, N. (2011). Primary Education Departments as the attraction of candidates for admission to Tertiary EducationThe views of their motivated selection at the Department of Primary Education of the University of Ioannina. In V. Economidis (Ed.): Teacher education and training. theoretical research approaches. Athens: Field, 7074.

Lampiri Dimaki, I. (1974). Towards a Greek Sociology of Education, volume a: Higher Education: Opportunities Obstacles. Athens: EKKE

Panagiotopoulos, N. (1995). Pierre Bourdieu: The thinker of the "primitive thought" of thinkers of "primitive thought". To I. Lampiri Dimaki \& N. Panagiotopoulos (Ed.): Pierre Bourdieu, Sociology of Education. Athens: KardamitsaDelphini, 2348.

Panagiotopoulos, N. (2005). The pain of the unemployed. Athens: Polytropos.

Panagiotopoulos, N., \& Thanos, Th. (2008). The time of understanding an unfair game. In N. Panagiotopoulos (Directorate): Deception of the world. Athens: EKEPPolytropon, 3772.

Parsons, T. (1985). The school class as a social system: Some of the functions in American society. To A. Frangoudakis (Metr.): Sociology of Education. Theories of social inequality in school. Athens: Papazisis, 249276.

Pyrgiotakis, I. (1992). The odyssey of the teaching profession. Thessaloniki: Kiriakides Brothers.

Reay, D. (1998). 'Always knowing' and never being sure: Familial and institutional habituses and higher education choice. Journal of Education Policy, 4, 519529.

Sianou Kirgiu, E. (2005). Education and social inequalities. The transition from Secondary to Higher (1997-2004). Athens: Metaxchio.

SianouKirgiou, E. (2010). From the University labor market. Aspects of social inequalities. Athens: Metaxchio.

Sianou Kyrgiou, E., \& Tsiplakides, I. (2011). Similar performance, but different choices: social class and higher education in Greece, Studies in Higher Education, 36 (1), 89102.

Tsukalas, K. (1987). State, society, work in post-war Greece. Athens: Foundation.

Frangoudaki, A. (1985). Educational sociology. Theories of social inequality in school. Athens: Papazisis. 


\section{ДОСТУП ДО ВИЩОЇ ОСВІТИ ТА СОЩІАЛЬНІ НЕРІВНОСТІ: СОЦІАЛЬНА ХАРАКТЕРИСТИКА СТУДЕНТІВ ШКОЛИ ОСВITHIX НАУК}

Марія Карантоні, аспірант, Грейія, mkarantoni83@gmail.com

Анотація. У статті досліджуються соціальні нерівності у доступі до вищої освіти. Основна увага у ній приділяється сочіальним характеристикам учнів Шкіл освітніх наук (Schools of Educational Sciences) у період 2001-2009 років. Інтерес до дослідження даного питання зумовлений розширенням доступу до вищої освіти в останні роки періоду, що досліджується, та актуалізацією проблеми соиіальної нерівності у доступі до вищої освіти на рівні теоретичних та емпіричних досліджень, як в Греції, так і на міжнародному рівні.

Метою даного дослідження було дослідити сочіально-демографічні характеристики учнів Школи освітніх наук та їх зміни протягом 2001-2009 років за такими критеріями, як: а) професія батька; б) професія матері; в) рівень освіти матері та г) стать студентів. Дослідження соиіально-демографічних характеристик проводилось у всіх Школах освітніх наук, а також на окремих факультетах початкової та дошкільної освіти.

Об'єктом дослідження стали студенти Шкіл освітніх наук. Джерелом даних - Статистика освіти, опублікована Грецьким управлінням статистики (ELSTAT, колишня ESYE) з 2001/02 по 2008/09 навчальні роки.

Встановлено, що абітурієнтами Шкіл освітніх наук були вихідиі із соиіального середовища з низьким економічним, освітнім та соиіальним капіталом. Представництво студентів жіночої статі у даному типі закладів було в п'ять разів більшим, ніж студентів чоловічої статі, що відображало притаманні суспільству стереотипи про сферу освіти дітей як суто жіночу професію. В останні роки досліджуваного періоду зазначені особливості контингенту студентів даного типів закладів вищої освіти стали мени вираженими внаслідок збільшення кількості вступників із сімей з високим освітнім рівнем батьків та збільшенням студентів чоловічої статі. Проте $i$ сьогодні Школи освітніх наук залишаються одним із «соиіальних ліфтів» для вихідиів з нижчих сочіальних класів суспільства.

Ключові слова: вища освіта; сочіальна нерівність; доступ до вищої освіти; студент; гендерні відмінності, науки про освіту. 